
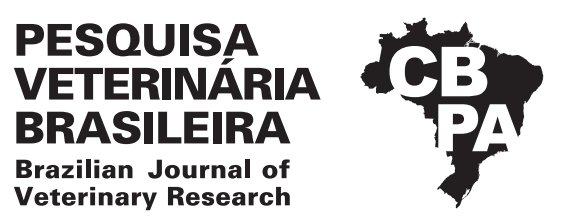

Pesq. Vet. Bras. 38(10):1942-1948, outubro 2018 DOI: 10.1590/1678-5150-PVB-5220

Original Article

ISSN 0100-736X (Print)

ISSN 1678-5150 (Online)

\title{
BI-RADS classification and gray level histogram of malignant mammary tumors in bitches ${ }^{1}$
}

\author{
Débora M.N.M. Oliveira ${ }^{2 *}$, Fabiano S. Costa $^{2}$ and Aurea Wischral ${ }^{2}$
}

\begin{abstract}
Oliveira D.M.N.M., Costa F.S. \& Wischral A. 2018. BI-RADS classification and gray level histogram of malignant mammary tumors in bitches. Pesquisa Veterinária Brasileira 38(10):1942-1948. Departamento de Medicina Veterinária, Universidade Federal Rural de Pernambuco, Rua Dom Manoel de Medeiros s/n, Dois Irmãos, Recife, PE 52171-900, Brazil. E-mail: deboramnavarro@gmail.com

Mammary tumor is the most frequent among the tumors that affect canine females, with relevant importance in veterinary medicine. The objective of this study was to determine the image characteristics of mammary tumors in female dogs, and compare different ultrasonographic techniques for neoplastic evaluation. During the experiment, 30 bitches with presence of nodular lesion in the mammary gland were used. Initially females were submitted to clinical and laboratory evaluations, and subsequent to the ultrasound examination of the tumor mass, as well as abdominal ultrasound and thoracic $\mathrm{x}$-ray for the metastasis investigation. Quantitative analysis by histogram of the gray levels and categorization of the tumor masses by the BI-RADS system were performed. Later, the bitches were submitted to surgical resection of the tumors, where samples of the neoplastic tissue were collected for histopathological analysis. Carcinoma in mixed tumor showed a higher rate $(33.3 \%)$, and the malignancy degree of epidermal tumors were classified in grade $1(n=9)$, grade $2(n=12)$ and grade $3(\mathrm{n}=3)$. Malignancy degree showed positive correlation with BI-RADS ( $\mathrm{r}=0.55$; $\mathrm{P}<0.05)$ and with the parameter echotexture - histogram base width $(\mathrm{r}=0.42, \mathrm{P}<0.05)$. BI-RADS graduation also showed a positive correlation with the echotexture parameters (standard deviation of average echogenicity $\mathrm{r}=0.66, \mathrm{P}<0.05$ and base width $\mathrm{r}=0.55, \mathrm{P}<0.05$ ). It was concluded that the BI-RADS method in combination with the echotexture of tumors, can be used to evaluate mammary tumors in dogs and establish the planning of treatment.

INDEX TERMS: BI-RADS, histogram, mammary tumors, bitches, ultrasound, dogs, neoplasm, breast, tumor.
\end{abstract}

RESUMO.- [Classificação BI-RADS e histograma dos níveis de cinza de tumores mamários malignos em cadelas.] Entre os tumores que acometem cadelas a neoplasia mamária é a de maior incidência, apresentando relevante importância na medicina veterinária. Este trabalho teve o objetivo de determinar as características ultrassonográficas de neoplasias mamárias em cadelas, e comparar diferentes técnicas ultrassonográficas de avaliação tumoral. Durante a realização deste experimento, foram utilizadas 30 cadelas com presença de lesão nodular em glândula mamária. Inicialmente as fêmeas foram submetidas a avaliações clínicas e laboratoriais, e subsequentemente à realização de exame ultrassonográfico da massa tumoral, assim como ultrassom abdominal e raio $\mathrm{x}$ torácico para a pesquisa de metástase. Foram realizadas a análise quantitativa por

\footnotetext{
${ }^{1}$ Received on May 5, 2017.

Accepted for publication on December 21, 2017.

${ }^{2}$ Departamento de Medicina Veterinária, Universidade Federal Rural de Pernambuco, Rua Dom Manoel de Medeiros s/n, Dois Irmãos, Recife, PE 52171-900, Brazil. *Corresponding author: deboramnavarro@gmail.com, fabianosellos@hotmail.com, aurea.wischral@gmail.com
}

histograma dos níveis de cinza e categorização das massas tumorais pelo sistema BI-RADS. Posteriormente as cadelas foram submetidas à ressecção cirúrgica dos tumores, onde foram coletadas amostras do tecido neoplásico para análise histopatológica. 0 carcinoma em tumor misto foi o tipo tumoral de maior incidência (33.3\%), e a graduação de malignidade dos tumores epiteliais foram classificadas em grau $1(n=9)$, grau $2(n=12)$ e grau $3(n=3)$. A graduação demonstrou correlação positiva com a categorização BI-RADS $(r=0,55 ; \mathrm{P}<0,05)$ e com o parâmetro de ecotextura - largura de base do histograma $(\mathrm{r}=0,42 ; \mathrm{P}<0,05)$. A graduação BI-RADS também demonstrou uma correlação positiva com os parâmetros de ecotextura (desvio padrão da média da ecogenicidade $\mathrm{r}=0,66 ; \mathrm{P}<0,05$ e largura de base $r=0,55 ; \mathrm{P}<0,05)$. Conclui-se que o método de categorização BI-RADS, assim como os parâmetros de ecotextura dos tumores, podem ser usados para avaliação de neoplasia mamária em cadelas e assim auxiliar no planejamento de tratamento de cada caso.

TERMOS DE INDEXAÇÃO: BI-RADS, histograma, tumores mamários malignos, cadelas ultrassom, caninos, neoplasias, mama, tumor. 


\section{INTRODUCTION}

Mammary neoplasia in bitches is considered the most frequent among neoplastic processes which affect female dogs, and their study has received added importance due to the existing similarity with various characteristics found in breast cancer in women (Mohammed et al. 2011, Shafiee et al. 2013, Cassali et al. 2014).

In human medicine, mammary ultrasound is an important tool for detecting and monitoring nodules in patients with an inconclusive mammography exam (Kuhl et al. 2005). Among the available diagnostic methods for mammary evaluation in small animals, ultrasonography has a key role in tissue analysis and distinguishing between benign and malignant tumors, thus aiding in selection of the best therapeutic choices for each patient (Nyman et al. 2006, Mohammed et al. 2011). This technique helps to gather information on the mammary parenchyma, such as characteristics related to size of the tumor, edges, internal and adjacent architecture, echogenicity, and echotexture (Bastan et al. 2009).

Due to being an operator-dependent exam and the lack of established criteria, the American College of Radiology (ACR) developed a system for classification and standardization of reports called BI-RADS ${ }^{\circledR}$ (Breast Imaging and Reporting Data System) (American College of Radiology 1993), which allows an evaluation focused on diagnostic evolution of mammary nodules and consequently a clinical/surgical recommendation based on the morphology of the echography findings (Calas et al. 2007). The BI-RADS ${ }^{\circledast}$, initially only used for mammography evaluations in women, underwent some updates in recent years, being adapted for ultrasound in 2003 (American College of Radiology 2003), and recently for the use in dogs (Mohammed et al. 2011).

Mammary ultrasound in bitches has been the focus of several studies in the last decades (Bastan et al. 2009, Feliciano et al. 2012), however, information on tumor differentiation, as well as standardization of this information, is scarce in the literature, which culminates sometimes in inconclusive reports.

Despite the standardization allowed by this technique, the BI-RADS ${ }^{\circledR}$ method is susceptible to some subjectivity in its evaluation, therefore new methods focusing on quantitative analyses have been proposed to aid in reducing subjectivity and operator dependency (Calas et al. 2007). Several studies in humans (Lee at al. 2006, Alvarenga et al. 2012, Moon et al. 2015) and animals (Silva et al. 2015, Zotti et al. 2015) analyze the characteristics of the pixel intensity of the ultrasound images, providing quantitative information on echotexture and echogenicity of the organ. In human medicine, quantitative ultrasound analysis is more precise for characterization of mammary neoplasms when compared with the BI-RADS ${ }^{\circledR}$ system. However, in animals, studies using this technique are restricted to the investigation of other organs (Ivani \& Mai 2008, Silva et al. 2015).

Establishing these parameters can have a fundamental importance in improving the quality of the assistance dedicated to oncology care in dogs, thus favoring a longer life for these patients. Because of this, and considering histopathology as a gold standard for classification of the neoplastic process, the objective of this study was to analyze the ultrasonographic aspect of mammary neoplasia in bitches using the BI-RADS system as well as histogram analysis, with the aim of increasing the precision in ultrasound differentiation of neoplasia and better guiding the therapy.

\section{MATERIALS AND METHODS}

Thirty bitches, without distinction of breed or age, were used. For each dog, an identification chart with data regarding their reproductive history was created, containing also information relative to anatomical location and time of development of the mammary nodules, as well as the main characteristics of the tumors. During macroscopic evaluation, consistency, dimensions, and degree of adherence of the lesions to the adjacent tissues was recorded, as well as presence or absence of ulcerated areas. In bitches with more than one nodule in their mammary glands, the largest identified mass was selected for analysis.

All ultrasound exams were performed using an ultrasound device with a microconvex multifrequency transducer ( 6 to $8 \mathrm{MHz}$ ), with the highest frequency selected for analysis of the tumors. During the exams, the bitches were manually held in right and/or left lateral recumbency.

Regarding the proposed BI-RADS classification, this was based on sonographic characteristics regarding shape, orientation, margin, echo pattern of the mass, and associated findings, as well as criteria relative to the presence of calcifications and internal and/or peripheral vascularization (Fig.1).

Following this analysis, lesions were classified according to the modified BI-RADS lexicon system, developed from the classification proposed by the American College of Radiology (2013) which standardizes 6 (six) categories with their respective suggestions of therapeutic procedures (Table 1).

In this study, the lexicon system was modified because it did not include in the evaluation a category zero present in the BI-RADS ${ }^{\circledR}$ lexicon, since that is characterized by an incomplete mammography
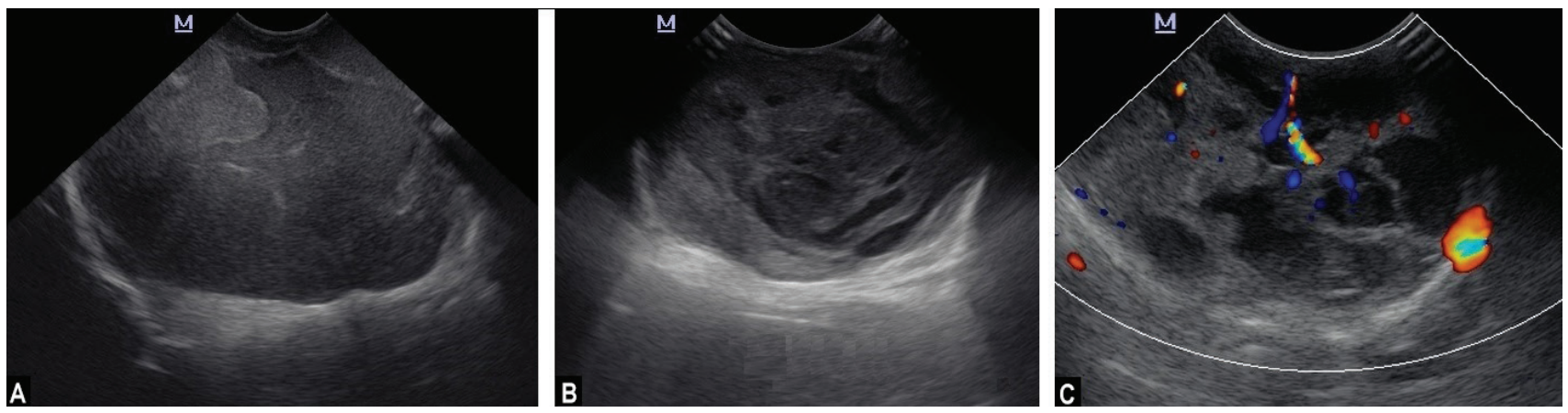

Fig.1. Ultrasound images of canine mammary tumors with varied imaging characteristics. (A) Echogenic mass with heterogeneous texture. (B) Mass with cavitations, showing mixed echogenicity and heterogeneous echotexture. (C) Doppler ultrasound of a mammary nodule with presence of intense internal and peripheral vascularization. 
evaluation that requires additional mammographies or techniques, an exam which is still little accessible in routine veterinary care.

For quantitative analysis of the lesions, gray level histogram analysis was used, based on the method described by Maeda et al. (1998). The ultrasound image in a longitudinal/transverse slice that best represented the tumor characteristics of each was selected and then analyzed using a computer program (GIMP $\left.{ }^{\circledR} 2.8 .14\right)$. The tumor was delimitated manually, and values regarding echogenicity and echotexture obtained (Fig.2). Echogenicity was characterized by the mean pixel intensity of the peaks observed in each sample (mean echogenicity). For echotexture analysis, standard deviation of the mean echogenicity of the selected region and the histogram base width for each sample was obtained, with this width being determined by the percentage of the graph base occupied by peaks of pixels.

After the imaging exams, the bitches underwent surgical resection of the mass, with subsequent measurement of the tumors (Fig.3) and collection of fragments for histopathology. Focusing on a categorization that allows a histological differentiation of the analyzed samples, malignancy was also graded according to Elston \& Ellis (1991), which restricts such histological grading to invasive carcinomas, and does not include tumors of mesenchymal origin. This method allows specific criteria to be systematically evaluated using parameters such as tubular formation index, nuclear pleomorphism and number of mitoses per field. For each of the three parameters mentioned above, scores varying from one to three according to the histological analysis are given. The degree of malignity is then given by the sum of the points, which can result in values ranging from three to nine. Histological evaluations with a result of three to five points are classified in grade I; Scores between six and seven, receive grade II, and results between eight and nine receive grade III (Elston \& Ellis 1991, Cassali et al. 2014).

Samples were fixed in formaldehyde at $10 \%(\mathrm{v} / \mathrm{v})$ prepared in PBS $0.01 \mathrm{M}$ and $7.2 \mathrm{pH}$. The fragments were divided and then processed according to routine techniques for inclusion in paraffin blocks, transected with a rotating microtome in 4 micrometers and stained using the routine hematoxylin-eosin (HE) technique. Histopathological

Table 1. Modified BI-RADS lexicon for ultrasound classification of canine mammary tumors, with respective therapy choices and expected malignancy percentages

\begin{tabular}{|c|c|c|c|}
\hline \multicolumn{2}{|r|}{ Categories } & Commentary/Actions & Probability of malignancy \\
\hline 1 & Negative & No lesion observed/Routine & $0 \%$ \\
\hline 2 & Benign & Findings without characteristics of malignancy/Routine & $0 \%$ \\
\hline 3 & Probably benign & Probably benign/Control (6 months) & 0 to $\leq 2 \%$ \\
\hline 4 & Suspicion of malignancy & Consider biopsy & \\
\hline $4 \mathrm{~A}$ & Low & Low probablity of malignancy & 2 to $\leq 10 \%$ \\
\hline $4 \mathrm{~B}$ & Moderate & Moderate probability of malignancy & 10 to $\leq 50 \%$ \\
\hline $4 \mathrm{C}$ & High & High probability of malignancy & 50 to $<95 \%$ \\
\hline 5 & Highly suggestive of malignancy & Consider biopsy/Adequate therapy choice for the case & $\geq 95 \%$ \\
\hline 6 & Confirmed malignancy & Diagnosis obtained from biopsy/Surgical excision when appropriate & - \\
\hline
\end{tabular}
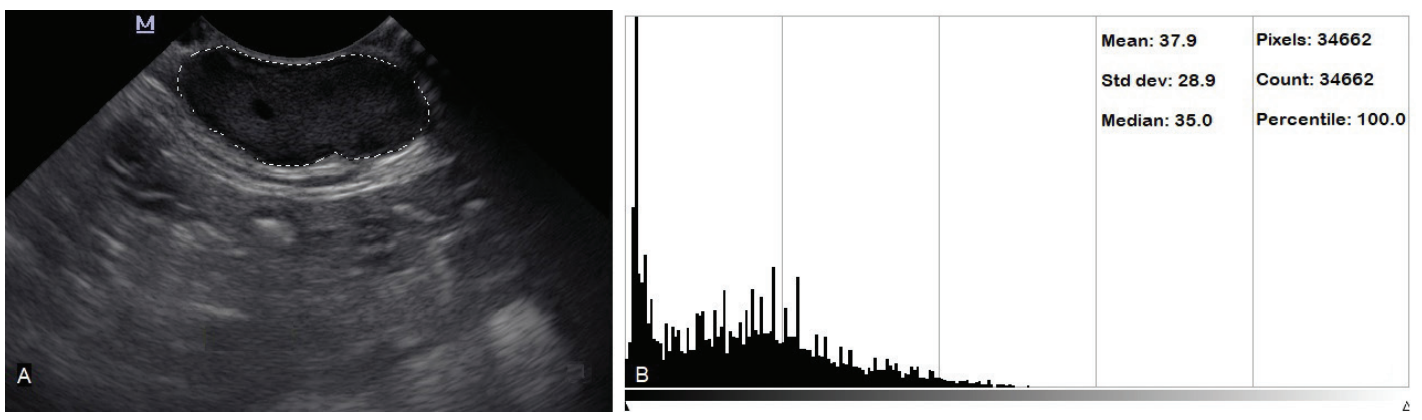

Fig.2. (A) Ultrasound image with selection of the region of interest corresponding to the mammary neoplasia. (B) Quantitative evaluation of the echogenicity and echotexture of the mammary tumor using gray level histogram analysis.
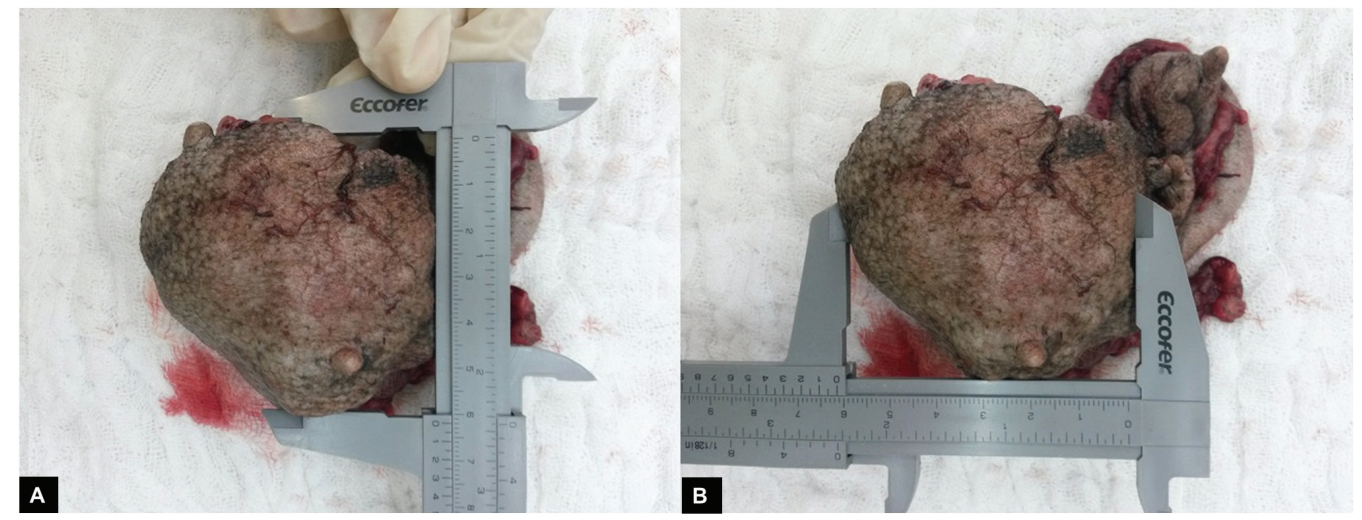

Fig.3. Surgical resection of breast neoformation demonstrating (A) the width and (B) length measurement of the tumor mass. 
diagnosis, as well as grading of the malignancy of the masses, was based on the classification proposed by Cassali et al. (2014). In the cases where there was not histopathological confirmation of mammary neoplasia, the animal was excluded from the sample.

The data were analyzed using a descriptive statistics tests as median and standard deviation. For correlation analysis were used Spearman's (non-parametric data) or Pearson's (parametric data) test. When needed, the original values were transformed into logarithm. The $\mathrm{P}$ value was considered significant when $\mathrm{P}<0.05$.

This study received the approval of the Ethics Committee for the Use of Animals (CEUA) of the Federal Rural University of Pernambuco, under license number 0095/2015.

\section{RESULTS}

The 30 bitches enrolled in this experiment had a mean age of $10.7 \pm 2.6$ years, and only 6 (six) females were spayed. On clinical exam, masses were observed with a mean size of $6.8 \pm 3.2 \mathrm{~cm}, 10 \%$ of which were ulcerated.

As for histopathology, all bitches had tumors that were classified as malignant, of which $80 \%$ of the cases were of epithelial origin, and mesenchymal tumors were less frequent $(20 \%)$. The tumor with the highest prevalence was the mixed carcinoma, which corresponded to $33.3 \%$ of the cases, followed by the tubular carcinoma with an occurrence of $20 \%$. Other tumor types were diagnosed less frequently (3.3\% each).

Analysis using the BI-RADS classification performed prior to surgical removal of the neoplasms showed varying grades between 3 and 5 , but the grade 5 was observed in higher frequency. Table 2 shows the frequency distribution of BI-RADS according to tumor type.

Regarding the degree of malignancy, nine of the 24 epithelial tumors were classified as Grade 1, twelve as Grade 2, and three as Grade 3. When looking at the relationship between degree of malignancy using histology and BI-RADS classification, there was a positive correlation between the variables $(\mathrm{r}=0.55, \mathrm{P}<0.05)$.

Quantitative analysis of the ultrasound images resulted in data regarding central tendency measurements for echotexture and echogenicity of the selected regions of interest. Mean echogenicity, standard deviation of the mean echogenicity, and histogram base width (\%) for the epithelial tumors were $42.29 \pm 10.83,21.50 \pm 7.84$, and 54.92 \pm 16.70 , respectively; while in the mesenchymal tumors, values were $46.85 \pm 14.97,21.23 \pm 8.07$, and $56.99 \pm 15.61$, respectively (Table 3 and 4 ).

Table 2. Frequency (\%) of the BI-RADS categories according to tumor type

\begin{tabular}{|c|c|c|c|c|c|c|c|c|}
\hline \multirow{3}{*}{ Mammary tumors } & \multicolumn{8}{|c|}{ BI-RADS (\%) } \\
\hline & \multirow[t]{2}{*}{1} & \multirow[t]{2}{*}{2} & \multirow[t]{2}{*}{3} & \multicolumn{3}{|c|}{4} & \multirow[t]{2}{*}{5} & \multirow[t]{2}{*}{6} \\
\hline & & & & A & $\mathrm{B}$ & $\mathrm{C}$ & & \\
\hline Mesenchymal $(n=6)$ & 0 & 0 & 1 (16.7) & 0 & 0 & 1 (16.7) & $4(66.6)$ & 0 \\
\hline
\end{tabular}

Table 3. Degree of malignancy, BI-RADS, mean and standard deviation of the histogram analysis in mammary tumors of epithelial origin in bitches

\begin{tabular}{|c|c|c|c|c|c|c|}
\hline \multirow{2}{*}{ Sample } & \multirow{2}{*}{ Histopathology } & \multirow{2}{*}{ Malignancy } & \multirow{2}{*}{ BI-RADS } & \multicolumn{3}{|c|}{ Histogram } \\
\hline & & & & $\mathrm{ME}$ & SD & BW (\%) \\
\hline 2 & Anaplastic carcinoma & II & 5 & 45.7 & 18.1 & 54.90 \\
\hline 4 & Tubular carcinoma & II & $4 \mathrm{C}$ & 41.5 & 18.7 & 47.84 \\
\hline 5 & Mucinous carcinoma & III & 5 & 50.5 & 21.5 & 56.07 \\
\hline 6 & Carcinoma in situ & II & 5 & 34.0 & 14.5 & 38.60 \\
\hline 9 & Solid carcinoma & II & 5 & 60.9 & 21.0 & 59.60 \\
\hline 10 & Mixed carcinoma & $\mathrm{I}$ & $4 \mathrm{C}$ & 27.4 & 13.3 & 36.86 \\
\hline 11 & Carcinoma in situ & II & $4 \mathrm{C}$ & 42.7 & 25.3 & 62.35 \\
\hline 12 & Mixed carcinoma & $\mathrm{I}$ & $4 \mathrm{~A}$ & 36.2 & 12.4 & 34.50 \\
\hline 13 & Papillary carcinoma & II & 5 & 55.3 & 34.8 & 82.74 \\
\hline 14 & Tubular carcinoma & II & 5 & 40.7 & 28.4 & 77.64 \\
\hline 20 & Tubular carcinoma & III & 5 & 60.7 & 29.8 & 89.41 \\
\hline 21 & Solid carcinoma & $\mathrm{I}$ & $4 \mathrm{~A}$ & 27.2 & 12.5 & 31.76 \\
\hline 22 & Mixed carcinoma & $\mathrm{I}$ & 5 & 28.2 & 16.3 & 49.01 \\
\hline 23 & Mixed carcinoma & I & 5 & 48.8 & 29.6 & 76.86 \\
\hline \multirow[t]{2}{*}{24} & Mixed carcinoma & $\mathrm{I}$ & 3 & 37.7 & 16.2 & 40.00 \\
\hline & Mean \pm sd & - & - & $42.29 \pm 10.8$ & $21.50 \pm 7.8$ & $54.92 \pm 16.7$ \\
\hline
\end{tabular}

ME = Mean echogenicity, $\mathrm{SD}=$ standard deviation for echogenicity, $\mathrm{BW}=$ base width 
Table 4. Degree of malignancy, BI-RADS, and mean and standard deviation of the histogram analysis in mammary tumors of mesenchymal origin in bitches

\begin{tabular}{|c|c|c|c|c|c|}
\hline \multirow{2}{*}{ Sample } & \multirow{2}{*}{ Histopathology } & \multirow{2}{*}{ BI-RADS } & \multicolumn{3}{|c|}{ Histogram } \\
\hline & & & $\mathrm{ME}$ & SD & BW (\%) \\
\hline 1 & Mixed sarcoma & 5 & 55.9 & 35.1 & 75.29 \\
\hline 2 & Fibrosarcoma & 5 & 54.0 & 18.9 & 49.01 \\
\hline 3 & Mixed sarcoma & $4 \mathrm{C}$ & 33.2 & 12.1 & 36.86 \\
\hline 4 & Hemangiosarcoma & 5 & 60.5 & 24.8 & 72.15 \\
\hline 5 & Liposarcoma & 5 & 54.3 & 20.9 & 45.09 \\
\hline \multirow[t]{2}{*}{6} & Malignant adenomyoepithelioma & 3 & 23.2 & 15.6 & 63.52 \\
\hline & Mean \pm sd & - & $46.85 \pm 14.9$ & $21.23 \pm 8.1$ & $56.99 \pm 15.6$ \\
\hline
\end{tabular}

$\mathrm{ME}=$ Mean echogenicity, $\mathrm{SD}=$ standard deviation of echogenicity, $\mathrm{BW}=$ base width .

A positive and significant correlation was observed between the ultrasound analysis using the BI-RADS method and the quantitative analysis using the histogram method, and the higher BI-RADS grade, the more echogenic and heterogenic was the aspect. A positive correlation was observed between echotexture measurements (deviation of the mean echogenicity $r=0.66, \mathrm{P}<0.05$ and base width $\mathrm{r}=0.55, \mathrm{P}<0.05$ ) and the BI-RADS classification.

As for histological grading of the malignancy grade, echogenicity, inferred from the intensity values of the pixels of the image, did not show a significant correlation ( $\mathrm{r}=0.27, \mathrm{P}>0.05)$, however, there was a positive correlation between the degree of malignancy and the BI-RADS classification $(\mathrm{r}=0.55, \mathrm{P}<0.05)$ and histogram base width $(\mathrm{r}=0.42, \mathrm{P}<0.05)$. The means for the ultrasound measurements according to the degree of malignancy are shown in Table 3 and 4.

A significant correlation was not observed between histopathological tumor types and ultrasound parameters.

\section{DISCUSSION}

This study looked at bitches with mammary tumors within an age group which coincides with studies that have proven that intact bitches older than 10 years of age had a higher incidence of mammary tumors, due to the greater exposure of the glandular parenchyma to hormonal factors which predispose to development of neoplasia (Mohammed et al. 2011, Cassali et al. 2014). Nodules were observed with mean size greater than six centimeters, a characteristic considered a prognostic factor for the evaluation of canine mammary tumors, suggesting that masses bigger than three centimeters are significantly correlated with a poor prognosis (Cassali et al. 2014).

Regarding the frequency of tumor types, mixed carcinomas had the higher incidence (33.3\%), which is in agreement with earlier studies that demonstrated a higher prevalence of tumors of epithelial origin among bitches with mammary neoplasia (Cassali et al. 2012, Tavasoly et al. 2013).

The use of the BI-RADS classification for mammary tumors is well-established in human medicine, however, its application in veterinary medicine is still restricted to a few studies such as the one performed by Mohammed et al. (2011), using the criteria established in the fourth published edition 2003 (American College of Radiology 2003). No study was found using the last edition (5th), published in 2013 (American College of Radiology 2013). To apply this technique in the canine species, the BI-RADS ${ }^{\circledR}$ lexicon system was adjusted to better fit the diagnostic tools available in veterinary medicine.
The zero category was excluded, since it encompasses mammary evaluations done using mammography, exam that is still little accessible routinely in veterinary care.

The use of the BI-RADS system can play an important role in small animal clinical oncology (Mohammed et al. 2011), something that is also observed from the significant correlation found in this study between the proposed BI-RADS classification and the degree of malignancy, demonstrating the efficacy of this technique. As in humans (Nascimento et al. 2009), this classification can work as a basis to guide future planning of invasive and/or surgical procedures necessary for identification of tumor type, minimizing aggressive procedures in patients with no indication for such procedures, as well as adoption of conservative measures when possible. This help in directing therapy options can be more effective when quantitative analysis is added to BI-RADS, which uses as base aspects related to echogenicity and echotexture of the tumors (Martin et al. 2006, Shen et al. 2007).

The degree of heterogenicity in mammary neoplasms, as determined from the gray level histogram, has demonstrated a positive correlation when compared with the BI-RADS classification and grading of histopathological malignancy of the samples. Factors related to tissue necrosis with their subsequent groupings of calcifications, frequently observed in malignant neoplasias (Cheville 2001, Martins et al. 2010), cause intense changes in tissue characteristics leading to different degrees of sound wave reflection with a consequent increase in heterogenicity of the neoplasia (Lima et al. 2013). In mammary neoplasia, a greater degree of malignancy is related to a higher mitotic index and fast tissue growth, which can lead to ischemia and necrosis (Jones et al. 1997, Cheville 2001).

Some types of malignant mammary tumors, especially mixed carcinomas, can develop cartilage islands and/or mineralized areas (Jones et al.1997), which on ultrasound are seen as hyperechoic with distal acoustic shadow (Lima et al. 2013). However, the presence of calcifications can occur in benign processes since this is a response of the body to earlier processes of healing and necrosis (Martins et al. 2010). Another factor that has been associated with mammary neoplasia of epithelial origin is malignant hypercalcemia, where there is an ectopic hypersecretion of peptides that mimic the activity of parathormone by the neoplastic cells. In these cases, there are clinical signs similar to hyperparathyroidism, increasing the possibility of calcification of soft tissues at a distance (Cheville 2001). 
Some malignant neoplasms of the mammary glands produce cavitary lesions with liquid content, such as the papillary carcinoma and the tubular carcinoma (Jones et al. 1997). On ultrasound, these lesions influence tissue heterogenicity and are characterized by an anechoic area with distal acoustic enhancement (Lima et al. 2013). However, this finding should not be used as the single criterion to suggest the degree of malignancy of the neoplasia, since, as described by Oliveira Filho et al. (2010), these lesions can also be observed in growth disturbances of the mammary glands, characterized as simple benign processes. Factors such as characteristics of the adjacent tissues, vascularization, and dimensions of the mass should be analyzed together to suggest a diagnosis (Cassali et al. 2014).

Regarding echogenicity of the neoplasms, there was no positive correlation with BI-RADS category, or with the degree of malignancy, with different degrees of echogenicity observed in the malignant neoplasms. The malignant mammary neoplasms presented several degrees of echogenicity depending on the severity of the changes to the neoplastic tissue, such as calcification, necrosis, and cellular differentiation.

\section{CONCLUSIONS}

Based on the results obtained, the BI-RADS method is related to the degree of malignancy of neoplastic lesions, suggesting a viable clinical application of this technique in bitches. Its use should be encouraged for a better planning of the surgical and/or chemotherapeutic treatment.

In the gray level histogram technique, echotexture was a more important prognostic factor than echogenicity, since the more heterogeneous the neoplastic mass has the greater the degree of malignancy.

Conflict of interest statement.- The authors have no competing interests.

Acknowledgments.- This research was supported by the CAPES scholarship program.

\section{REFERENCES}

Alvarenga A.V., Infantosi A.F.C., Pereira W.C.A. \& Azevedo C.M. 2012. Assessing the combined performance of texture and morphological parameters in distinguishing breast tumors in ultrasound images. Med. Phys. 39(12):73507358. <http://dx.doi.org/10.1118/1.4766268> <PMid:23231284>

American College of Radiology. 1993. Breast Imaging Reporting and Data System (BI-RADS). American College of Radiology, Reston, VA

American College of Radiology. 2003. Breast Imaging Reporting and Data System Ultrasound, BIRADS ${ }^{\mathrm{T}}$-Ultrasound. American College of Radiology, Reston, VA.

American College of Radiology. 2013 Breast Imaging Reporting and Data System (BI-RADS). 5th ed. American College of Radiology, Reston, VA.

Bastan A., Özenç E. \& Pir Yagci I. 2009. Ultrasonographic evaluation of mammary tumors in bitches. Kafkas Üniversitesi Veteriner Fakültesi Dergisi 1(15):81-86.

Calas M.J.G., Koch H.A. \& Dutra M.V.P. 2007. Breast ultrasound: evaluation of echographic criteria for diferenciation of breast lesions. Radiol. Bras. 40:1-7. <http://dx.doi.org/10.1590/S0100-39842007000100003>

Cassali G.D., Bertagnolli A.C., Ferreira E., Damasceno K.A., Gamba C.O. \& Campos C.B. 2012. Canine mammary mixed tumours: a review. Vet. Med. Int. 2012:1-7.<http://dx.doi.org/10.1155/2012/274608><PMid:23193497>
Cassali G.D., Lavalle G.E., Ferreira E., Estrela-Lima A., De Nardi A.B., Ghevers C., Sobral R.A., Amorim R.L., Oliveira L.O., Sueiro F.A.R., Beserra H.E.O., Bertagnolli A.C., Gamba C.O., Damasceno K.A., Campos C.B., Araujo M.R., Campos L.C., Monteiro L.N., Nunes F.C., Horta R.S., Reis D.C., Luvizotto M.C.R., Magalhães G.M., Raposo J.B., Ferreira A.M.R., Tanaka N.M., Grandi F., Ubukata R., Batschinski K., Terra E.M., Salvador R.C.L., Jark P.C., Delecrodi J.E.R., Nascimento N.A., Silva D.N., Silva L.P., Ferreira K.C.R.S., Frehse M.S. Di Santis G.W., Silva E.O., Guim T.N., Kerr B., Cintra P.P., Silva F.B.F., Leite J.S., Mello M.F.V., Ferreira M.L.G., Fukumasu H., Salgado B.S. \& Torres R. 2014. Consensus for the diagnosis, prognosis and treatment of canine mammary tumors, 2013. Braz. J. Vet. Pathol. 7(2):38-69.

Cheville N.F. 2001. Introduction to Veterinary Pathology. 2nd ed. WileyBlackwel, New York. (CD-ROM)

Elston C.W. \& Ellis I.O. 1991. Pathological prognostic factors in breast cancer. I. The value of histological grade in breast cancer: experience from a large study with long-term follow-up. Histopathology 19(5):403-410. <http:// dx.doi.org/10.1111/j.1365-2559.1991.tb00229.x><PMid:1757079>

Feliciano M.A.R., Vicente W.R.R. \& Silva M.A.M. 2012. Conventional and Doppler ultrasound for the differentiation of benign and malignant canine mammary tumours. J. Small Anim. Pract. 53(6):332-337. <http://dx.doi. org/10.1111/j.1748-5827.2012.01227.x><PMid:22647211>

Ivani M. \& Mai W. 2008. Qualitative and quantitative comparison of renal vs hepatic ultrasonographic intensity in healthy dogs. Vet. Radiol. Ultrasound 49(4):368-373. <http://dx.doi.org/10.1111/j.1740-8261.2008.00383.x> $<$ PMid:18720770>

Jones T.C., Hunt R.D. \& King N.W. 1997. Veterinary Pathology. 6th ed. Blackwell, New York, USA

Kuhl C.K., Schrading S., Leutner C.C., Morakkabati-Spitz N., Wardelmann E. Fimmers R., Kuhn W. \& Schild H.H. 2005. Mammography, breast ultrasound, and magnetic resonance imaging for surveillance of women at high familial risk for breast cancer. J. Clin. Oncol. 23(33):8469-8476. <http://dx.doi. org/10.1200/JC0.2004.00.4960 > <PMid:16293877>

Lee C.H., Choi J.W., Kim K.A., Seo T.S., Lee J.M. \& Park C.M. 2006. Usefulness of standard deviation on the histogram of ultrasound as a quantitative value for hepatic parenchymal echo texture: preliminary study. Ultrasound Med. Biol 32(12):1817-1826.<http://dx.doi.org/10.1016/j.ultrasmedbio.2006.06.014> <PMid:17169693>

Lima J.L.S., André A. \& Santos A.C. 2013. Reproduction and study of artifacts in ultrasound. Revta Bras. Fis. Med. 7(3):205-208.

Maeda K., Utsu M. \& Kihaile P.E. 1998. Quantification of sonographic echogenicity with grey-level histogram width: A clinical tissue characterization. Ultrasound Med. Biol. 24(2):225-234. <http://dx.doi.org/10.1016/S03015629(97)00266-4><PMid:9550181>

Martin K.E., Helvie M.A., Zhou C., Roubidoux M.A., Bailey J.E., Paramagul C., Blane C.E., Klein K.A., Sonnad S.S. \& Chan H. 2006. Mammographic density measured with quantitative computer-aided method: comparison with radiologists' estimates and BI-RADS categories. Radiology 240(3):656665. <http://dx.doi.org/10.1148/radiol.2402041947><PMid:16857974>

Martins L.A.L., Barra A.A. \& Lucena C.E.M. 2010. Breast microcalcifications suspected of malignancy. Revta Bras. Cancerol. 56(2):251-258.

Mohammed S.I., Meloni G.B., Pinna Parpaglia M.L., Marras V., Burrai G.P., Meloni F., Pirino S. \& Antuofermo E. 2011. Mammography in ultrasound imaging of preinvasive and invasive canine spontaneous mammary cancer and their similarities to human breast cancer. Cancer Prev. Res. 4(11):1790-1798. <http://dx.doi.org/10.1158/1940-6207.CAPR-11-0084><PMid:21803985>

Moon W.K., Huang Y., Lo C., Huang C., Bae M.S., Kim W.H., Chen J. \& Chang R. 2015. Computer-aided diagnosis for distinguishing between triple-negative breast cancer and fibroadenomas based on ultrasound texture features. Med. Phys. 42(6):3024-3035. <http://dx.doi.org/10.1118/1.4921123> <PMid:26127055>

Nascimento J.H.R., Silva V.D. \& Maciel A.C. 2009. Accuracy of sonographic findings in breast cancer: correlation between BI-RADS categories 
and histological findings. Radiol. Bras. 42(4):235-240. <http://dx.doi. org/10.1590/S0100-39842009000400009>

Nyman H.T., Kristensen A.T., Lee M.H., Martinussen T. \& McEvoy F.J. 2006. Characterization of canine superficial tumors using gray-scale B-mode, color flow mapping, and spectral Doppler ultrasonography-a multivariate study. Vet. Radiol. Ultrasound 47(2):192-198. <http://dx.doi. org/10.1111/j.1740-8261.2006.00127.x><PMid:16553153>

Oliveira Filho J.C., Kommers G.D., Masuda E.K., Marques B.M.F.P.P., Fighera R.A., Irigoyen L.F. \& Barros C.S.L. 2010. Estudo retrospectivo de 1.647 tumores mamários em cães. Pesq. Vet. Bras. 30(2):177-185. <http:// dx.doi.org/10.1590/S0100-736X2010000200014>

Shafiee R., Javanbakht J., Atyabi N., Kheradmand P., Kheradmand D., Bahrami A., Daraei H. \& Khadivar F. 2013. Diagnosis, classification and grading of canine mammary tumours as a model to study human breast cancer: an clinico-cytohistopathological study with environmental factors influencing public health and medicine. Cancer Cell Int. 13(79):79. < PMid:23937693>
Shen W.C., Chang R., Moon W., Chou Y. \& Huang C. 2007. Breast ultrasound computer-aided diagnosis using BI-RADS features. Acad. Radiol. 14(8):928939. <http://dx.doi.org/10.1016/j.acra.2007.04.016><PMid:17659238>

Silva E.G., Gonçalves M.T.C., Pinto S.C.C., Soares D.M., Oliveira R.A., Alves F.R., Araújo A.V.C. \& Guerra P.C. 2015. Quantitative analysis of testicular echogenicity by technical histogram in sheep of the western lowland region of Maranhão, Brazil. Pesq. Vet. Bras. 35(3):297-303. <http://dx.doi. org/10.1590/S0100-736X2015000300014>

Tavasoly A., Golshahi H., Rezaie A. \& Farhadi M. 2013. Classification and grading of canine malignant mammary tumors. Vet. Res. Forum 4(1):2530. <PMid:25593682>

Zotti A., Banzato T., Gelain M.E., Centelleghe C., Vaccaro C. \& Aresu L. 2015. Correlation of renal histopathology with renal echogenicity in dogs and cats: an ex-vivo quantitative study. BMC Vet. Res. 11(99):99. <http://dx.doi. org/10.1186/s12917-015-0415-8><PMid:25909709> 